\title{
Kajian Hubungan Allometrik dan Biomassa Lamun Thalassia hemprichii sebagai Bioindikator Lingkungan
}

\section{(Assessment of Allometric and Biomass Relationship in Thalassia hemprichii Seagrass as an Environmental Bioindicator)}

\author{
Andi Zulfikar $^{1^{\star}}$, Mennofatria Boer ${ }^{2}$, Luky Adrianto ${ }^{2}$, Reny Puspasari ${ }^{3}$
}

(Diterima Januari 2020/Disetujui Mei 2020)

\begin{abstract}
ABSTRAK
Lamun merupakan tumbuhan laut yang sensitif terhadap perubahan lingkungan, terutama akibat aktivitas manusia (antropogenik) dan telah sering digunakan sebagai bioindikator untuk kondisi lingkungan. Penelitian ini bertujuan untuk mengetahui struktur interaksi antarmetrik (allometrik dan biomasa) pada wilayah dengan tekanan antropogenik yang tinggi (pemukiman) dan wilayah dengan tekanan antropogenik yang rendah (nonpemukiman) menggunakan lamun $\boldsymbol{T}$. hemprichii. Penelitian yang dilakukan adalah penelitian konfirmatif melalui pembentukan model konseptual berdasarkan hasil-hasil penelitian terdahulu, kemudian model konseptual tersebut diuji melalui analisis multivariat menggunakan data observasi lapang. Hasil penelitian menunjukkan dominasi Thalassia hemprichii pada wilayah pemukiman yang merefleksikan adanya input nutrien yang tinggi dengan kecenderungan nilai metrik yang lebih besar pada bagian atas (daun), sedangkan pada wilayah nonpemukiman menunjukkan nilai metrik yang lebih tinggi pada bagian bawah. Bagian atas Thalassia hemprichii yang memberikan dampak langsung pada biomasa atas dan bawahnya adalah lebar daun, sedangkan panjang daun mempunyai dampak tidak langsung. Struktur hubungan allometrik lamun jenis $T$. hemprichii menunjukkan beberapa kovariasi metrik berbeda secara signifikan antar- dan dalam kedua wilayah pemukiman dan nonpemukiman, yang terutama dipengaruhi oleh tingkat kepadatan T. hemprichii yang berbeda. Panjang daun, lebar daun, kelimpahan, dan tutupan $T$. hemprichii berpotensi untuk dapat digunakan sebagai komponen indeks dan bioindikator kualitas lingkungan.
\end{abstract}

Kata kunci: analisis lajur, model persamaan struktural, tekanan antropogenik, Thalassia hemprichii

\section{ABSTRACT}

Seagrass has long been known to be very sensitive to environmental changes, especially caused by human activities (anthropogenic disturbance) and has been used as a bioindicator for environmental condition. This research aimed to study interaction of Thalassia hemprichii measured and derived variables (metrics), at two locations i.e., inhabited island (high anthropogenic location) and uninhabited island (low anthropogenic location). Confirmative approach was conducted using a developed conceptual model based on preliminary studies, the conceptual model was analyzed in multivariate context using data from field observation. The result showed that Thalassia hemprichii dominated and have higher above ground biomass value in inhabited area which indicated high nutrient input, meanwhile uninhabited area showed a higher below ground biomass value. Above ground of Thalassia hemprichii that have direct effect on its biomass and below ground metrics was leaf width, meanwhile leaf length of Thalassia hemprichii have indirect effect on its biomass and below ground metrics. The result also indicated some different metric covariations which were influenced by the degree of Thalassia hemprichii density. Leaf length, leaf width, density, and percent cover of Thalassia hemprichii potentially could be used as components in multimetric index and bioindicator for environmental quality.

Keywords: anthropogenic disturbance, path analysis, structural equation modeling, Thalassia hemprichii

\section{PENDAHULUAN}

Padang lamun (seagrass meadow) merupakan salah satu komunitas pantai yang membentuk hu-

${ }^{1}$ Fakultas IImu Kelautan dan Perikanan, Universitas Maritim Raja Ali Haji Tanjungpinang, Jl. Politeknik Senggarang, Tanjungpinang 29100

2 Departemen Manajemen dan Sumberdaya Perairan, Fakultas Perikanan dan Ilmu Kelautan, Institut Pertanian Bogor, Kampus IPB Darmaga, Bogor 16680

3 Pusat Penelitian Pengelolaan Perikanan dan Konservasi Sumberdaya Ikan Jln. Pasir Putih I, Ancol Timur, Jakarta 14430

* Penulis Korespondensi: Email: andizulfikar099@gmail.com bungan integratif dengan vegetasi daratan (mangrove) dan terumbu karang (Hogarth 2015). Lamun adalah tumbuhan berbunga (Angiospermae) yang hidup terendam dalam kolom air dan berkembang dengan baik di perairan laut dangkal dan estuari. Tumbuhan lamun terdiri atas daun dan seludang, batang menjalar yang biasanya disebut akar rimpang (rizom), dan akar yang tumbuh pada bagian rizom. Hingga saat ini diketahui terdapat 13 jenis lamun yang tersebar di hampir seluruh perairan dangkal Hindia Bagian Barat, termasuk perairan Indonesia (El Shaffai 2016).

Lamun cukup responsif terhadap perubahan kondisi lingkungan sekitarnya (Marba et al. 2013), terutama 
perubahan lingkungan akibat tekanan atau gangguan oleh aktivitas manusia (antropogenik). Lamun banyak digunakan sebagai bioindikator status kondisi lingkungan, khususnya yang terkait dengan gangguan antropogenik, melalui pengembangan indeks multimetrik kualitas lingkungan (Roca et al. 2016).

Thalassia hemprichii merupakan jenis lamun tropis yang paling sensitif terhadap tekanan lingkungan dan merupakan produser primer utama di pantai tropis (Van Tussenbroek 2006). Thalassia hemprichii juga merupakan jenis yang paling banyak dan sering ditemukan di wilayah Taman Nasional Laut, Kepulauan Seribu (Setyawan et al. 2011; Feryatun et al. 2012; Wahab et al. 2017) tempat penelitian ini dilakukan. Jenis ini mempunyai potensi dan sangat sesuai untuk digunakan sebagai kandidat bioindikator kualitas lingkungan di perairan Indonesia.

Beberapa peneliti menyimpulkan bahwa beberapa metrik lamun menunjukkan keterkaitan satu-sama lain. Congdon et al. (2017) memberikan kesimpulan bahwa terdapat hubungan garis lurus (linear) antara tutupan lamun dan biomasa atas dan bawah lamun (Thalassia testudinum, Halodule wrightii dan Syringodium filiforme). Lyons et al. (2015) membuat kuantifikasi biomasa atas lamun dengan menggunakan persen tutupan daun sebagai prediktor pada padang lamun dengan jenis campuran. Tekanan antropogenik (terutama melalui buangan nutrien berlebih ke perairan) memengaruhi hubungan antar-metrik lamun (Roca et al. 2016; Armitage \& Fourqurean 2016; Fraser \& Kendrick 2017; Angelina et al. 2019).
Gangguan dan ancaman, baik secara alami maupun akibat tekanan antropogenik pada ekosistem padang lamun, merupakan suatu keniscayaan. Pemahaman mengenai interaksi antar-metrik lamun terkait dengan kondisi lingkungannya penting untuk diketahui, terutama dalam tahap pemilihan indikator-indikator (metrik) yang akan digunakan sebagai komponen penilaian dalam indeks multimetrik. Wilayah dengan tekanan antropogenik yang berbeda diduga memberikan struktur interaksi yang juga berbeda. Interaksi multimetrik tersebut dapat dianalisis secara simultan dengan menggunakan pendekatan multivariat, seperti model persamaan struktural (structural equation modeling atau SEM).

Penelitian ini bertujuan untuk mengetahui struktur interaksi antar-metrik (allometrik dan biomasa) pada wilayah dengan tekanan antropogenik yang tinggi (pemukiman) dan wilayah dengan tekanan antropogenik yang rendah (nonpemukiman) menggunakan lamun T.hemprichii.

\section{METODE PENELITIAN}

\section{Lokasi}

Pengambilan data lapangan dilakukan pada bulan Juli-Oktober 2018 di Taman Nasional Laut, Kepulauan Seribu (TnLKs) Jakarta (Gambar 1).

Delapan padang lamun dipilih dalam wilayah pemukiman (wilayah dengan tekanan antropogenik
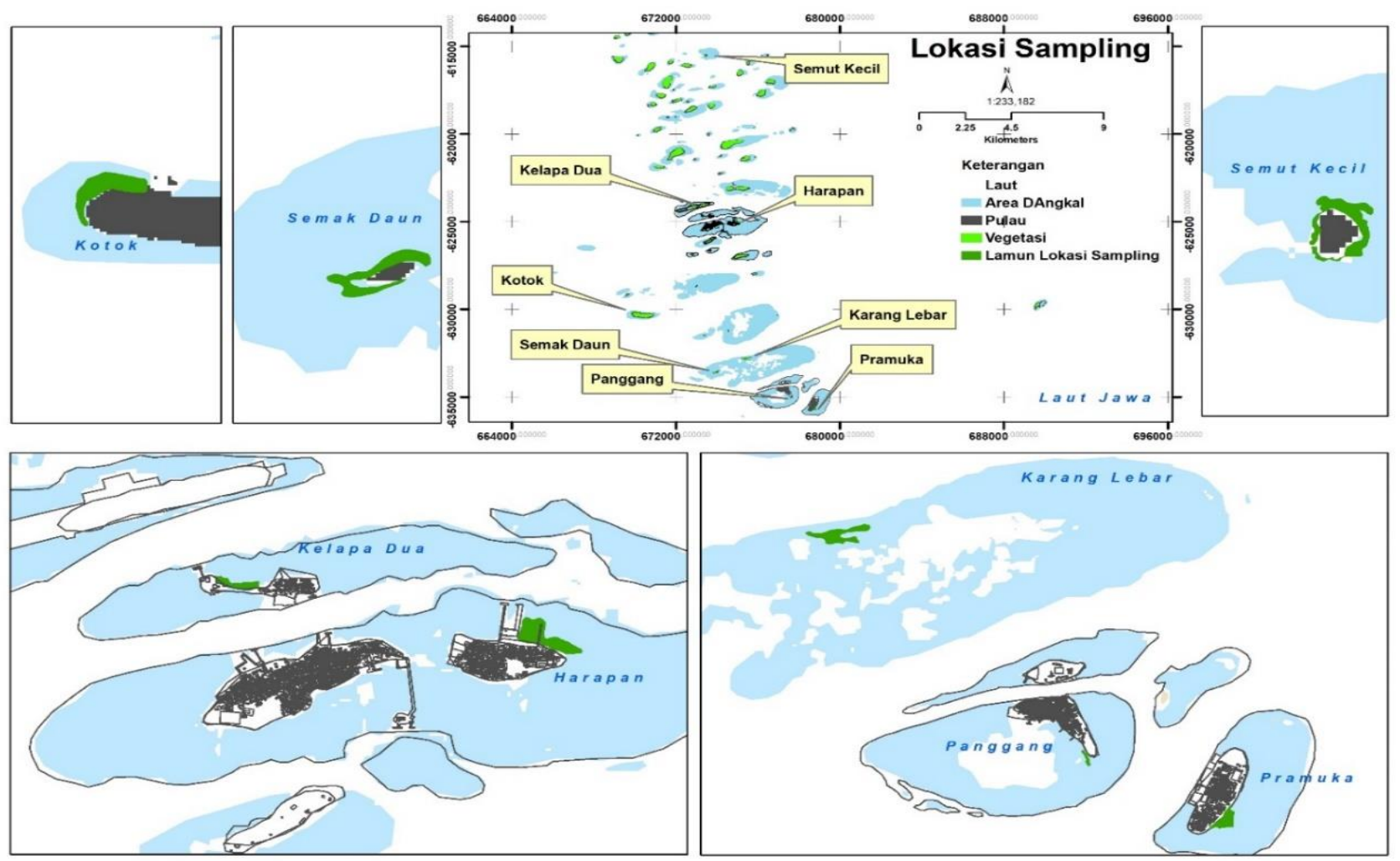

Gambar 1 Lokasi penelitian di Taman Nasional Laut, Kepulauan Seribu, Jakarta. 
tinggi) dan nonpemukiman (wilayah dengan tekanan antropogenik rendah). Pada masing-masing wilayah dipilih sebanyak 4 lokasi padang lamun. Wilayah pemukiman dan nonpemukiman yang dipilih, yaitu:

\section{- Pemukiman}

Pulau Panggang, Pramuka, Kelapa Dua, dan Harapan merupakan pulau berpenduduk sangat padat dengan tingkat pembangunan dan reklamasi pantai yang sangat ekspansif.

\section{- Nonpemukiman}

Terdiri atas tiga pulau yang tidak berpenghuni (Pulau Semut Kecil, Kotok, dan Semak Daun) dan satu paparan karang (Karang Lebar). Dua pulau (Pulau Semut Kecil dan Kotok) merupakan pulau pribadi dengan akses terbatas, sedangkan Pulau Semak Daun merupakan pulau wisata. Karang Lebar merupakan area paparan karang dengan banyak laguna (goba) tanpa pulau.

\section{Desain Penelitian dan Akuisisi Data}

Pengambilan sampel dilakukan menggunakan metode sampling tersarang bertingkat (hierarchical nested sampling design), di mana lokasi (8 Lokasi padang lamun) tersarang dalam status (pemukiman dan nonpemukiman). Zona (intertidal dan subtidal) tersarang dalam lokasi dan status. Sebanyak 121 kuadrat $\left(0,25 \times 0,25 \mathrm{~m}^{2}\right)$ disebar dengan pola acak sistematis (systematic random pattern of points) menggunakan perangkat lunak $\mathrm{R}$ v.3.6.1 ( $R$ Core Team, 2019) dan paket $R$ spatstat (Baddeley et al. 2015). Jarak antar-kuadrat dalam satu lokasi berkisar antara 30-34 m. Status dianggap merupakan prediktor atau variabel bebas dengan pengaruh tetap (fixed effect). Lokasi dan zona merupakan prediktor dengan pengaruh acak (random efect). Zona pada masingmasing status dan lokasi diberikan identitas (ID) yang berbeda pada analisis sehingga setiap zona mempunyai ID yang unik untuk tiap status dan lokasi.

Pengamatan tutupan $T$. hemprichii dan jenis lamun lainnya dilakukan secara visual pada tiap kuadrat, kepadatan $T$. hemprichii dihitung dalam tiap kuadrat berdasarkan jumlah tegakan (shoot). Semua $T$. hemprichii yang ada dalam kuadrat diambil meng- gunakan sekop, untuk dilakukan pengukuran morformetrik dan biomassa. Panjang daun, lebar daun, diameter rizom, dan rizom vertikal diukur menggunakan jangka sorong (rataan dari 5-10 daun dan 3-5 rizom). Lebar daun berasal dari rataan bagian atas (dekat ujung bagian atas daun), tengah daun, dan batas bawah area hijau daun. Biomassa diukur dalam gram bobot kering (g DW). Bagian-bagian T. hemprichii yang diukur ditunjukkan pada Gambar 2 dan metrikmetrik yang digunakan disajikan dalam Tabel 1.

\section{Analisis Data}

Tahapan analisis penelitian yang dilakukan adalah sebagai berikut:

- Uji sebaran normal ganda pada data mentah dilakukan sebelum analisis utama, menggunakan uji Mardia dalam paket $R$ MVN (Korkmaz et al. 2014).

- Penentuan model dasar (model konseptual) untuk analisis lajur yang dibangun berdasarkan hasil-hasil penelitian yang telah disebutkan pada bagian pendahuluan di atas, disajikan pada Gambar 3.

Analisis lajur merupakan bagian Structural Equation Modeling (SEM) yang hanya melibatkan variabel yang

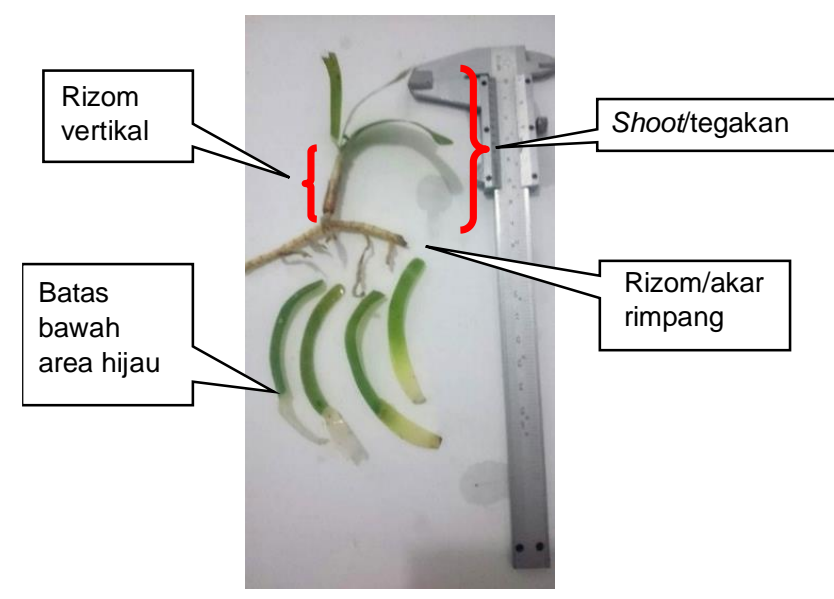

Gambar 2 Bagian-bagian T. hemprichii yang diukur (sebagai metrik atau indikator).

Tabel 1 Metrik dan deskripsi lamun yang digunakan dalam penelitian

\begin{tabular}{|c|c|c|}
\hline Metrik (unit) & Kode & Deskripsi \\
\hline Panjang daun (cm) & $\mathrm{Pd}$ & Rataan panjang area hijau daun \\
\hline Lebar daun $(\mathrm{cm})$ & Ld & Rataan lebar area hijau daun \\
\hline Panjang rizom vertikal (cm) & $\mathrm{Rv}$ & Panjang rizom vertikal \\
\hline Diameter rizom $(\mathrm{cm})$ & $\mathrm{Dr}$ & Diameter rizom \\
\hline Biomassa bawah (g bobot kering/g DW) & $\mathrm{Bb}$ & $\begin{array}{l}\text { Rataan bobot rizom dan area nonfotosintetik setelah } \\
\text { dikeringkan selama } 48 \text { jam pada suhu } 60^{\circ} \mathrm{C}\end{array}$ \\
\hline Biomassa atas (g DW) & $\mathrm{Ba}$ & $\begin{array}{l}\text { Rataan bobot area hijau daun setelah dikeringkan selama } \\
48 \text { jam pada suhu } 60^{\circ} \mathrm{C}\end{array}$ \\
\hline Tutupan T. hemprichii (\%) & Tut_Th & $\begin{array}{l}\text { Estimasi visual tutupan } T \text {. hemprichii dalam kuadrat } 0,25 \\
\times 0,25 \mathrm{~m}^{2}\end{array}$ \\
\hline Kepadatan (jumlah tegakan $\mathrm{m}^{-2}$ ) & K & Jumlah tegakan dalam kuadrat $0,25 \times 0,25 \mathrm{~m}^{2}$ \\
\hline Total tutupan jenis lain (\%) & Tut_OT & $\begin{array}{l}\text { Estimasi visual tutupan jenis lainnya dalam kuadrat } 0,25 \\
x 0,25 \mathrm{~m}^{2}\end{array}$ \\
\hline
\end{tabular}

Sumber: Buia et al. (2004). 


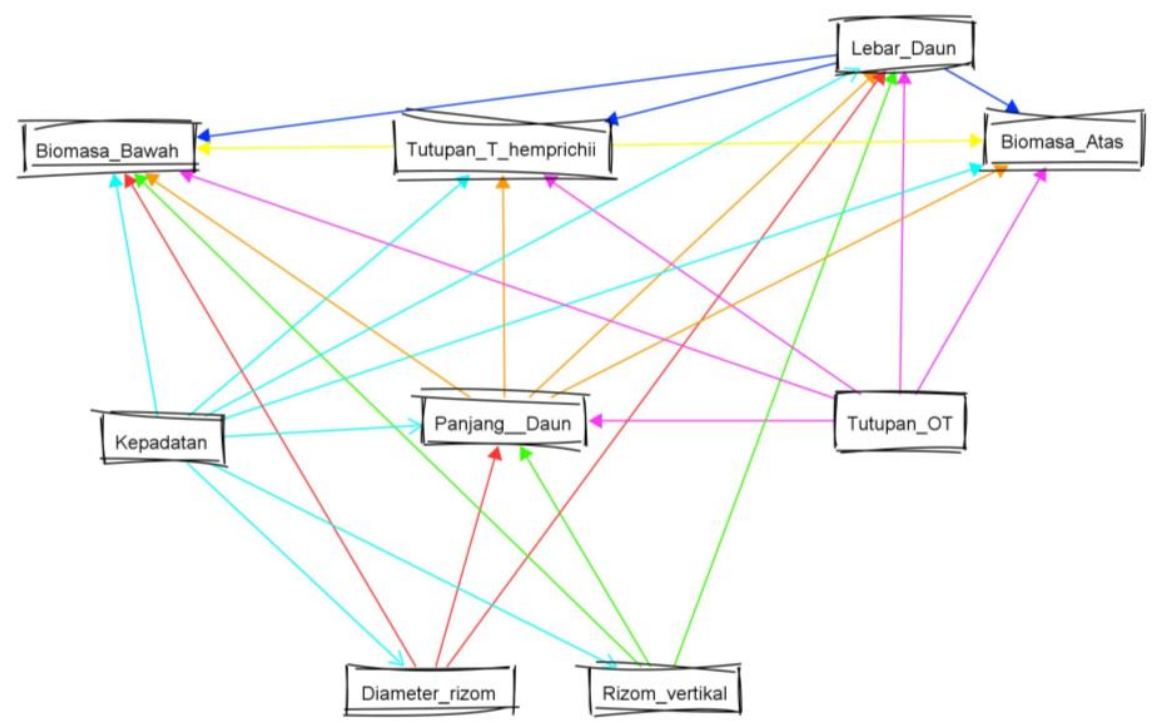

Gambar 3 Model konseptual analisis lajur (path analysis). Pengaruh satu komponen metrik ditunjukkan oleh warna panah yang sama.

diobservasi. Sistem persamaan simultan diterapkan menggunakan diagram lajur melalui penguraian ragam dan korelasi, pemisahan antara pengaruh langsung dan tidak langsung serta pengaruh total suatu variabel pada variabel lain (Mattjik \& Sumertajaya 2011).

Terdapat 5 variabel respons (variabel terikat) dalam model konseptual lajur yang disajikan pada Gambar 3 yaitu:

- Tutupan T. hemprichii sebagai respons kepadatan, lebar daun, panjang daun, dan tutupan jenis lain.

- Biomassa atas sebagai respons panjang daun, tutupan jenis lain, tutupan T. hemprichii, kepadatan, dan lebar daun.

- Biomasa bawah sebagai respons diameter rizom, rizom vertikal, kepadatan, lebar daun, tutupan $T$. hemprichii, tutupan jenis lain, dan panjang daun.

- Panjang daun sebagai respons kepadatan, diameter rizom, rizom vertikal, dan tutupan jenis lain.

- Lebar daun sebagai respons kepadatan, diameter rizom, rizom vertikal, tutupan jenis lain, dan panjang daun.

Tahapan analisis lajur pada model konseptual menggunakan paket $R$ piecewise SEM (Lefcheck 2016) yang meliputi:

- Pengujian model konseptual apakah terdapat potensi hubungan antar-metrik yang tidak terwakili dalam model yang seharusnya ada berdasarkan informasi dari data mentah, menggunakan metode $d$ separasi (d-separated) atau directed acyclic graphs (DAGs) (Shipley 2009). Berdasarkan rujukan penelitian terdahulu, terdapat 8 hubungan yang diasumsikan tidak signifikan dalam model konseptual penelitian ini (tidak ada notasi tanda panah dalam diagram lajur pada Gambar 3). Jika hasil uji $d$ separasi menunjukkan hasil $p$ value $>$ 0,05 mengindikasikan justifikasi penghilangan hubungan tersebut dalam diagram lajur. Uji struktur model dasar secara keseluruhan dilihat melalui nilai Fisher's $C$ yang dihitung menggunakan rumus (Shipley 2009):

$$
C=-2 \sum_{i=1}^{k} \ln (p i)
$$

di mana $k$ adalah jumlah klaim ketidakberhubungan dalam model konseptual (8 hubungan), $i$ adalah klaim ke-i, dan $p$ adalah nilai $p$ value uji signifikansi lajur terkait. Nilai probabilitas hasil uji $(p$ value $)>$ 0,05 mengimplikasikan bahwa hipotesis struktur model konseptual tidak berbeda dari struktur korelasi dalam data mentah, artinya tidak terindikasi adanya potensi kemungkinan hilangnya lajur yang signifikan dalam model konseptual.

- Estimasi koefisien lajur menggunakan analisis model efek campuran (mixed effect models dengan 2 efek acak, yaitu lokasi dan zona) pada masingmasing struktur hubungan 5 variabel respons $(\mathrm{Pd}$, $\mathrm{Ld}$, Tut_Th, Ba, dan $\mathrm{Bb}$ ) dengan variabel-variabel bebasnya yang dilakukan secara simultan menggunakan paket $R$ nlme (Pinheiro et al. 2019).

- Analisis lajur multikelompok (multigroup analysis) menggunakan model hasil analisis tahap kedua dengan status (pemukiman dan nonpemukiman) sebagai kelompok.

\section{HASIL DAN PEMBAHASAN}

\section{Uji Sebaran Normal Ganda dan Kondisi Umum Lamun T. hemprichii}

Hipotesis nol uji Mardia untuk sebaran normal ganda adalah data tidak berbeda dari sebaran normal. 
Hasil uji menunjukkan simpangan sebaran normal pada dua Lokasi (karang lebar dan semak daun) dengan nilai kurtosis $-2,19$ ( $p$ value 0,03 pada $\alpha 0,05$ ) untuk karang lebar dan $-2,24$ ( $p$ value 0,03 pada $\alpha 0,05$ ) untuk semak daun. Dua Lokasi ini tetap dimasukkan ke dalam analisis dengan pertimbangan hasil tersebut tidak terlalu jauh menyimpang dari pola sebaran normal.

T. hemprichii banyak ditemukan dan dominan di perairan dangkal dekat pantai dan pemukiman, pada beberapa kuadrat dekat pemukiman malah hanya ditemukan jenis T.hemprichii. Gambar 4 menunjukkan sebaran $T$. hemprichii pada wilayah pemukiman dan nonpemukiman. Thalassia hemprichii dengan tutupan sangat padat hanya dijumpai pada wilayah permukiman, sedangkan pada wilayah nonpemukiman kondisi tutupan $T$. hemprichii didominasi oleh tutupan jarang dan sedang dan semakin jauh ke arah utara wilayah kajian (wilayah yang didominasi oleh pulaupulau pribadi dan tidak berpenghuni) jenis ini semakin jarang ditemukan. Kegiatan monitoring selama periode 2005-2009 yang dilakukan oleh Setyawan et al. (2011) juga melaporkan kondisi serupa, yaitu pada umumnya lamun dengan tutupan yang padat banyak dijumpai pada wilayah pemukiman.

Ali et al. (2018) juga menemukan lamun $T$. hemprichii yang dekat dengan area industri dan aktivitas maritim (pemukiman) menunjukkan karakter daun yang lebih panjang dan lebih berat dibandingkan wilayah lain di Singapura, dan berargumen bahwa hal ini merefleksikan ketersediaan nutrien yang tinggi pada perairan. Pemupukan lamun (nitrat, ammonia, total nitrat, fosfat, dan kalium) yang secara eksperimental dilakukan oleh Agawin et al. (1996) menunjukkan Ionjakan pertumbuhan dan morfologi lamun Enhalus acoroides dan $T$. hemprichii dibandingkan dengan padang lamun yang tidak ditambahkan pengayaan pupuk di perairan Filipina. Jones \& Unsworth (2016) menyatakan padang lamun Zostera marina di Selat Inggris yang terpapar input nutrien menunjukkan kepadatan yang lebih tinggi dan membentuk padang yang lebih luas. Burkholder et al. (2007) dalam ulasannya menyatakan adanya peningkatan pertumbuhan lamun dalam kondisi pengayaan nutrien baik pada level rendah maupun moderat.

Secara umum $T$. hemprichii pada wilayah permukiman menunjukkan kecenderungan nilai metrik yang lebih besar pada bagian atas (daun) sedangkan $T$. hemprichii pada wilayah nonpemukiman menunjukkan nilai metrik yang lebih tinggi pada bagian bawah (Tabel 2).

Lyon et al. (2015) dan Congdon et al. (2017) menyatakan adanya keterkaitan linear antara persen tutupan atau kelimpahan lamun dengan biomasa bagian atas dan Christon et al. (2012) menyatakan produktivitas daun yang lebih tinggi (bagian atas lamun) ditunjukkan oleh lamun dengan kepadatan yang tinggi. Akan tetapi, Vonk et al. (2015) dan Congdon et al. (2017) menyatakan hubungan linear antara persen tutupan atau kelimpahan dengan biomasa bagian bawah lamun menunjukkan respons yang beragam dan tidak kuat, dalam arti hubungan antara persen tutupan dan kelimpahan lamun tidak selalu berbanding lurus dengan nilai biomasa bagian bawahnya. Kecenderungan metrik bagian bawah yang lebih tinggi pada area nonpemukiman yang mempunyai kelimpahan dan persen tutupan yang lebih rendah dibandingkan dengan area pemukiman pada penelitian ini, menegaskan hal tersebut. Tutupan dan kepadatan (jenis $T$. hemprichii maupun jenis lamun lain) yang lebih rendah pada area nonpemukiman, mengindikasikan tingkat kompetisi ruang yang lebih rendah pada padang lamun area nonpemukiman, dan memungkinkan lebih tingginya ekspansi dan/atau pertumbuhan bagian bawah lamun (akar rimpang atau rizom).

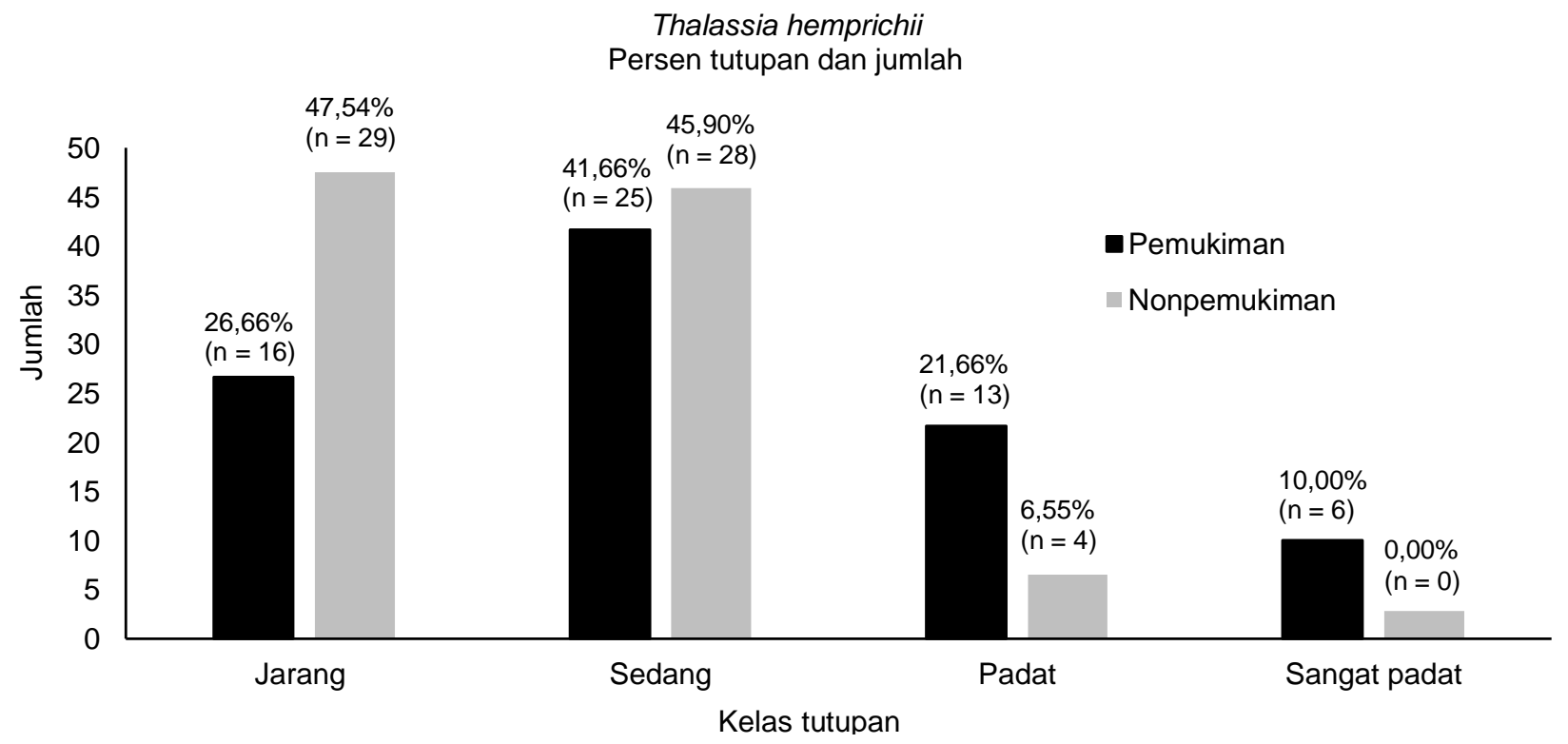

Gambar 4 Perbandingan tutupan T. hemprichii pada wilayah pemukiman dan nonpemukiman. 


\section{Analisis Lajur (Path analysis)}

Uji $d$ separasi menunjukkan tidak terdapat potensi lajur yang tidak terwakili dalam model konseptual (semua $p$ value $>0,05$ dengan nilai Fisher's $C=$ 18,266, $p$ value $=0,309$, dan derajat bebas 16). Analisis model efek campuran memperlihatkan beberapa hubungan yang tidak signifikan dalam model. Hasil analisis multikelompok menunjukkan struktur model dasar yang tidak berbeda antara wilayah pemukiman dan nonpemukiman (nilai Fisher's $C=$
$10,688, p$ value $=0,828$, dan derajat bebas 16$)$, tetapi analisis model campuran dalam hubungan lajur menunjukkan dua lajur yang berbeda secara signifikan antara wilayah pemukiman dan nonpemukiman, yaitu respons Biomassa bawah $(\mathrm{Bb})$ dan lebar daun (Id) terhadap rizom vertikal (Rv) serta respons diameter rizom (Dr) terhadap kelimpahan (K) (Gambar 5). Walaupun pengaruh $\mathrm{K}$ pada $\mathrm{Dr}$ dan pengaruh Rv pada Ld menunjukkan signifikansi yang berbeda antara wilayah pemukiman dan nonpemukiman, pengaruh $\mathrm{K}$

Tabel 2 Deskripsi metrik T. hemprichii pada wilayah pemukiman dan nonpemukiman

\begin{tabular}{|c|c|c|c|c|c|c|}
\hline Status & Metrik & Min & Maks & Rataan & Median & Simpangan baku \\
\hline & $\mathrm{Pd}(\mathrm{cm})$ & 5,56 & 15,54 & 9,25 & 8,77 & 2,51 \\
\hline & $\mathrm{Ld}(\mathrm{cm})$ & 0,56 & 0,93 & 0,75 & 0,75 & 0,09 \\
\hline & $\mathrm{Rv}(\mathrm{cm})$ & 0,54 & 6,52 & 2,06 & 1,84 & 1,06 \\
\hline & $\operatorname{Dr}(\mathrm{cm})$ & 0,30 & 0,62 & 0,39 & 0,38 & 0,04 \\
\hline \multirow[t]{9}{*}{ Pemukiman } & Tut_Th (\%) & 10,00 & 90,00 & 42,06 & 38,25 & 21,34 \\
\hline & $\mathrm{K}$ (jumlah shoot $\mathrm{m}^{-2}$ ) & 24,00 & 640,00 & 215,67 & 200,00 & 127,69 \\
\hline & $\mathrm{Bb}(\mathrm{g} \mathrm{DW})$ & 0,29 & 0,67 & 0,44 & 0,45 & 0,10 \\
\hline & $\mathrm{Ba}(\mathrm{g} D W)$ & 0,01 & 0,21 & 0,05 & 0,04 & 0,03 \\
\hline & Tut_OT (\%) & 25,00 & 90,00 & 57,58 & 62,50 & 21,42 \\
\hline & $\mathrm{Pd}(\mathrm{cm})$ & 5,71 & 12,27 & 8,03 & 7,58 & 1,57 \\
\hline & $\mathrm{Ld}(\mathrm{cm})$ & 0,51 & 1,01 & 0,67 & 0,66 & 0,09 \\
\hline & $\mathrm{Rv}(\mathrm{cm})$ & 0,95 & 7,46 & 3,22 & 3,08 & 1,44 \\
\hline & $\operatorname{Dr}(\mathrm{cm})$ & 0,29 & 0,46 & 0,36 & 0,36 & 0,04 \\
\hline \multirow[t]{5}{*}{ Nonpemukiman } & Tut_Th (\%) & 8,00 & 70,00 & 29,78 & 30,00 & 15,14 \\
\hline & $\mathrm{K}$ (jumlah tegakan $\mathrm{m}^{-2}$ ) & 10,00 & 320,00 & 109,95 & 112,00 & 69,48 \\
\hline & $\mathrm{Bb}(\mathrm{g} \mathrm{DW})$ & 0,30 & 1,27 & 0,57 & 0,53 & 0,18 \\
\hline & $\mathrm{Ba}(\mathrm{g} D W)$ & 0,01 & 0,13 & 0,04 & 0,04 & 0,02 \\
\hline & Tut OT (\%) & 20,00 & 85,00 & 46,31 & 40,00 & 19,08 \\
\hline
\end{tabular}

Keterangan: $\mathrm{Pd}=$ Panjang daun; $\mathrm{Ld}=$ Lebar daun; Rv = Rizom vertikal; $\mathrm{Dr}=$ Diameter rizom; Tut_Th = Tutupan $T$. hemprichii; $\mathrm{K}=$ Kelimpahan; $\mathrm{Bb}=$ Biomassa bawah; $\mathrm{Ba}=$ Biomasa atas; dan Tut_OT = Tutupan lamun selain jenis T. hemprichii.
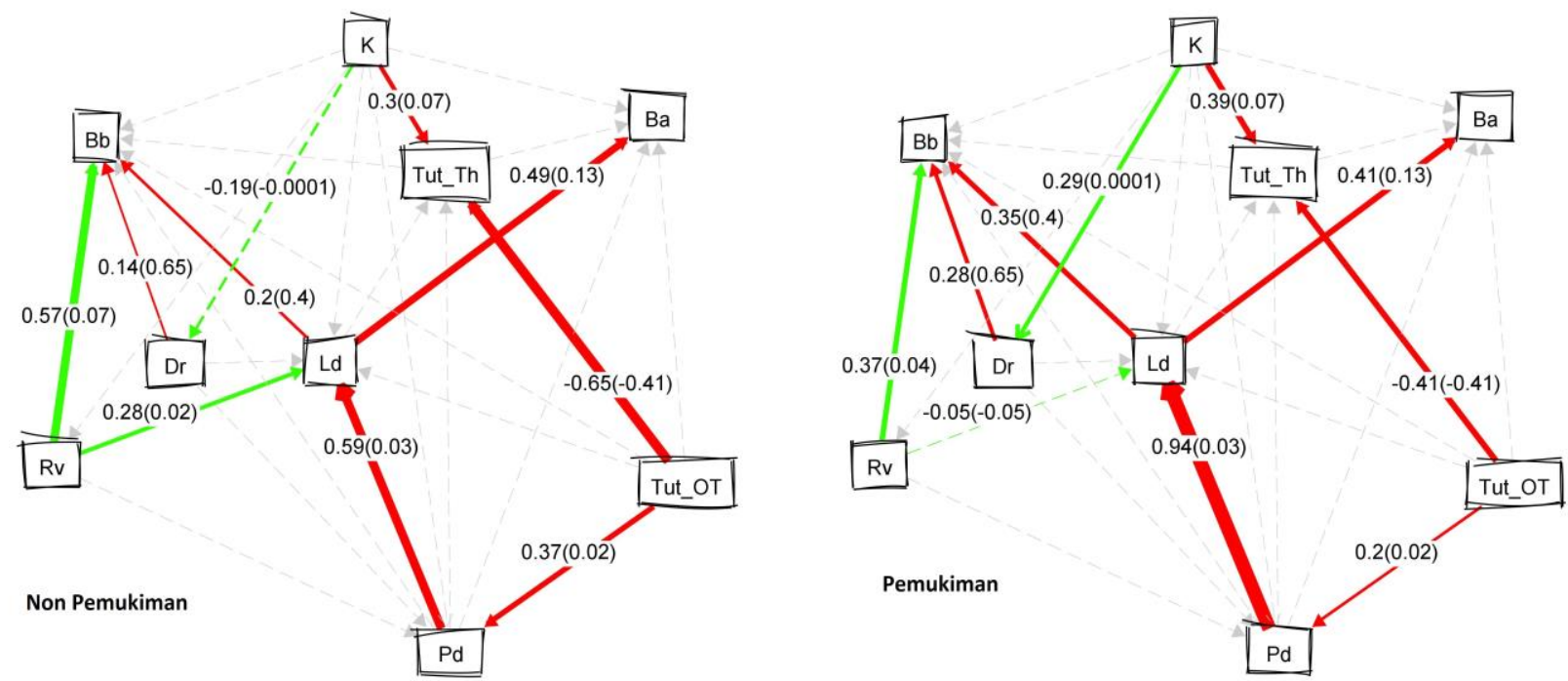

Gambar 5 Diagram lajur hasil analisis multikelompok. Angka dalam kurung merupakan nilai ragam/variance, garis putusputus menunjukkan lajur yang tidak signifikan. Warna merah menunjukkan lajur yang tidak berbeda secara signifikan antar-wilayah pemukiman dan nonpemukiman, tetapi signifikan dalam masing-masing wilayah; Warna hijau menunjukkan lajur yang berbeda secara signifikan antar-wilayah (ketebalan garis berdasarkan skala nilai korelasi). 
pada Dr hanya signifikan dalam wilayah pemukiman, sedangkan pengaruh $\mathrm{Rv}$ pada Ld hanya signifikan dalam wilayah nonpemukiman.

Wilayah nonpemukiman menunjukkan kovariasi positif yang lebih kuat antara $\mathrm{Bb}$ dan $\mathrm{Rv}$ dibandingkan dengan wilayah pemukiman, kovariasi Ld dan Rv pada wilayah pemukiman menunjukkan kovariasi negatif, sedangkan pada wilayah nonpemukiman sebaliknya. Lamun pada kedua wilayah rata-rata terbenam dalam pasir (sediment burial), tetapi lebih jelas terlihat pada wilayah pemukiman, dampak aktivitas penambangan pasir lokal, reklamasi, dan penangkapan ikan. Keterbenaman ini diduga merupakan penyebab perbedaan kondisi Rv pada kedua wilayah. Cabaco et al. (2008) menyatakan respons lamun terhadap kondisi keterbenaman bervariasi antar-jenis dan memengaruhi panjang $R v$ dan seludang daun (sheat) yang membungkus Rv pada lamun. Kepadatan T. hemprichii yang lebih tinggi pada wilayah pemukiman berpengaruh pada $\mathrm{Dr}$, dan fenomena ini berbanding terbalik pada wilayah nonpemukiman dan peran $\mathrm{Dr}$ dalam $\mathrm{Bb}$ lebih besar pada wilayah pemukiman. Berdasarkan hasil ulasannya dari berbagai literatur, Duarte (1991) menyatakan hubungan yang kuat antara Dr dan metrik lamun lainnya pada berbagai jenis lamun, termasuk $T$. hemprichii, tetapi pada penelitian ini hanya menemukan hubungan antara $\mathrm{K}, \mathrm{Bb}$, dan $\mathrm{Dr}$.

Secara umum, tutupan (Tut_Th) signifikan dipengaruhi oleh kelimpahan (K) dan tutupan jenis lain (Tut_OT) (kovariasi negatif), Ba hanya dipengaruhi oleh $\mathrm{Ld}, \mathrm{Bb}$ dipengaruhi oleh $\mathrm{Ld}, \mathrm{Rv}$ dan $\mathrm{Dr}, \mathrm{Pd}$ dipengaruhi oleh Tut_OT, sedangkan Ld dipengaruhi oleh Pd dan Rv. Hubungan Tut_OT yang negatif dengan Tut_Th pada kedua wilayah menunjukkan kompetisi spasial antara $T$. hemprichii dengan jenis lainnya, terutama pada padang lamun jenis campuran di wilayah nonpemukiman di mana $T$. hemprichii tidak banyak ditemukan pada area utama padang lamun, tetapi tersebar di sekitar pinggiran area padang lamun.

Bagian atas $T$. hemprichii yang signifikan memengaruhi biomassa bawah secara langsung hanya ditunjukkan oleh $\mathrm{Ld}$, sedangkan pengaruh $\mathrm{Pd}$ pada $\mathrm{Bb}$ melalui mediasi Ld (untuk wilayah nonpemukiman sebesar $0,2 \times 0,59=0,12$ dan 0,33 untuk wilayah pemukiman). $\mathrm{Pd}$ dan $\mathrm{Ld}$ memengaruhi area luasan daun dan indeks area daun (Buia et al. 2004) dan menentukan kemampuan lamun dalam berfotosintesis serta menyerap karbon (Samper-Villareal et al. 2016). Potensi ini lebih tampak dalam wilayah pemukiman. Hal ini diduga karena kepadatan yang tinggi dan adanya asupan nutrien dari buangan limbah rumah tangga pada wilayah pemukiman seperti yang disimpulkan oleh Ali et al. (2018). Rizom vertikal (Rv) kuat memengaruhi Biomasa bawah $(\mathrm{Bb})$ karena terdapat seludang daun (sheat) yang membungkus Rv (semakin panjang $R v$ seludang daun juga semakin tebal dan panjang) dan mengindikasikan Rv pada wilayah nonpemukiman relatif lebih panjang dibandingkan dengan di wilayah pemukiman. Hal ini mengindikasikan keterbenaman (burial) lamun pada area nonpemukiman lebih rendah dibandingkan dengan area pemukiman, seperti yang dinyatakan oleh Cabaco et al. (2008) bahwa keterbenaman akan memengaruhi morfologi Rv. Biomasa atas $(\mathrm{Ba})$ hanya signifikan dipengaruhi secara langsung oleh lebar daun (Ld), Panjang daun (Pd) memengaruhi Ba melalui Ld (wilayah nonpemukiman sebesar 0,3 dan wilayah pemukiman 0,4). Lyon et al. (2015) dan Congdon et al. (2017) memberikan kesimpulan serupa dalam membangun model linear hubungan antara biomassa atas dan panjang dan lebar daun, yang menyimpulkan keterkaitan yang cukup kuat antara bagian atas dan morfologi daun.

Berbeda dari kesimpulan Congdon et al. (2017) untuk 3 jenis lamun pada wilayah nontropis (Thalassia testudinum, Halodule wrightii, dan Syringodium filiforme), penelitian ini tidak menunjukkan hubungan signifikan antara persen tutupan $T$. hemprichii dan biomassa atas dan bawahnya. Perbedaan ini karena Congdon et al. (2017) melakukan analisis bivariat antara biomassa dan persen tutupan dengan metode regresi linear sederhana, sedangkan dalam penelitian ini menggunakan analisis model campuran dengan memperhitungkan zona dan lokasi tersarang dalam status serta lebih dari satu prediktor untuk biomassa.

\section{KESIMPULAN}

Thalassia hemprichii banyak ditemukan dan dominan di perairan dangkal dekat pantai dan wilayah pemukiman yang merefleksikan adanya input nutrien yang tinggi pada wilayah pemukiman. Thalassia hemprichii pada wilayah pemukiman menunjukkan kecenderungan nilai metrik yang lebih besar pada bagian atas (daun), sedangkan T. hemprichii di wilayah nonpemukiman menunjukkan nilai metrik yang lebih tinggi pada bagian bawah. Bagian atas $T$. hemprichii yang memberikan dampak langsung pada biomasa atas dan bawahnya adalah lebar daun, sedangkan panjang daun mempunyai dampak tidak langsung. Hasil penelitian mengimplikasikan adanya pengaruh antropogenik pada struktur hubungan antar-metrik lamun T. hemprichii. Struktur hubungan allometrik lamun jenis $T$. hemprichii menujukkan beberapa kovariasi metrik berbeda secara signifikan antar- dan dalam kedua wilayah pemukiman dan nonpemukiman, yang terutama dipengaruhi oleh tingkat kepadatan T. hemprichii yang berbeda. Panjang daun, lebar daun, kelimpahan dan tutupan $T$. hemprichii berpotensi dapat digunakan sebagai komponen indeks dan bioindikator kualitas lingkungan.

\section{UCAPAN TERIMA KASIH}

Penelitian ini didanai oleh Lembaga Pengelola Dana Pendidikan (LPDP) Kementerian Keuangan Republik Indonesia. 


\section{DAFTAR PUSTAKA}

Agawin NSR, Duarte CM, Fortes MD.1996. Nutrient limitation of Philippine seagrasses (Cape Bolinao, NW Philippines): in situ experimental evidence. Marine Ecology Progress Series. 138: 233-243. https://doi.org/10.3354/meps138233

Ali MS, He J, Goh PLB, Sin MT. 2018. Environmental correlates of Thalassia hemprichii status descriptors: an evaluation of tools for diagnostic monitoring. Botanica Marina. 61: 3 https://doi.org/ 10.1515/bot-2017-0083

Angelina I, Sartimbul A, Wahyudi J. 2019. The potential of seagrass beds on the coast of Putri Menjangan as a carbon sequestration ecosystem on Bali Island. IOP Conf. Series: Earth and Environmental Science. 241: 012010. https://doi.org/10.1088/ 1755-1315/241/1/012010

Armitage AR, Fourqurean JW.2016. Carbon storage in seagrass soils: long-term nutrient history exceeds the effects of near-term nutrient enrichment. Biogeosciences. 13: 313-321. https://doi.org/ 10.5194/bg-13-313-2016

Baddeley A, Rubak E, Turner R. 2015 Spatial Point Patterns: Methodology and Applications with R. London (EN): Chapman and Hall/CRC Press. https://doi.org/10.1201/b19708

Buia MC, Gambi MC, Dappiano M. 2004. Seagrass System. Biologia Marina Mediterrania. 11: 133-183.

Burkholder JM, Tomasko DA, Touchette BW. 2007. Seagrasses and eutrophication. Journal of Experimental Marine Biology and Ecology. 350: 46-72. https://doi.org/10.1016/j.jembe.2007. 06.024

Cabaço S, Santos R, Duarte CM. 2008. The impact of sediment burial and erosion on seagrasses: A review. Estuarine, Coastal, and Shelf Science. 79: 354-366. https://doi.org/10.1016/j.ecss.2008. 04.021

Christon, Djunaedi OS, Purba NP. 2012. Pengaruh Tinggi Pasang Surut Terhadap Pertumbuhan dan Biomassa Daun Lamun Enhalus acoroides di Pulau Pari Kepulauan Seribu Jakarta. Jurnal Perikan dan Kelautan. 3: 287-294.

Congdon VM, Wilson SS, Dunton KH. 2017. Evaluation of Relationships Between Cover Estimates and Biomassa in Subtropical Seagrass Meadows and Application to Landscape Estimates of Carbon Storage. Southeastern Geographer. 57(3): 231245. https://doi.org/10.1353/sgo.2017.0023

Duarte CM. 1991. Allometric Scaling of Seagrass Form and Productivity. Marine Ecology Progress Series. 77: 289-300. https://doi.org/10.3354/meps 077289
El Shaffai A. 2016. Field Guide to Seagrasses of the Red Sea. Second Edition.56 pp. Gland (CH) : IUCN

Feryatun F, Hendrarto B, Widyorini N. 2012. Kerapatan dan distribusi lamun (seagrass) berdasarkan zona kegiatan yang berbeda di perairan Pulau Pramuka, Kepulauan Seribu. Journal of management of aquatic resources. Halaman 1-7.

Fraser MW, Kendrick GA. 2017. Belowground stressors and long-term seagrass declines in a historically degraded seagrass ecosystem after improved water quality. Scientific Reports. 7: 14469. https://doi.org/ 10.1038/s41598-017-14044-1

Jones BL, Unsworth RKF. 2016. The perilous state of seagrass in the British Isles. Royal Society Open Science. 3: 150596. https://doi.org/10.1098/rsos. 150596

Hogarth PJ. 2015. The Biology of Mangroves and Seagrasses.Third Edition. Oxford (EN): Oxford University Press. https://doi.org/10.1093/acprof: oso/9780198716549.001.0001

Korkmaz S, Goksuluk D, Zararsiz G. 2014. MVN: An R Package for Assessing Multivariate Normality. The $R$ Journal. 6(2): 151-162. https://doi.org/10.32614/ RJ-2014-031

Lefcheck JS. 2016. piecewiseSEM: piecewise structural equation modelling in $r$ for ecology, evolution, and systematics. Methods in Ecology and Evolution. 7: 573-579. https://doi.org/10.1111/ 2041-210X.12512

Lyons M, Roelfselma C, Covacs E, Samper-Villareal J, Saunders M., Maxwell P, Phinn S. 2015. Rapid monitoring of seagrass biomassa using a simple linear modelling approach, in the field and from space. Marine Ecology Progress Series. 530: 1-14. https://doi.org/10.3354/meps11321

Marbà N, Krause-Jensen D, Alcoverro T, Birk S, Pedersen A, Neto JS, Orfanidis S, Garmendia JM, Muxika I, Borja A, Dencheva K, Duarte CM. 2013. Diversity of European seagrass indicators: patterns within and across regions. Hydrobiologia.704: 265-278. https://doi.org/10.1007/s10750-0121403-7

Mattjik AA, Sumertajaya IM. 2011. Sidik Peubah Ganda. Bogor (ID): IPB Press.

Pinheiro JC, Bates DM. 2000. Mixed-effects models in $S$ and S-plus. New York (US): Springer.

$\mathrm{R}$ Core Team. 2019. Perangkat lunak yang saya gunakan, yang saya tahu seperti ini sitasinya. R: A language and environment for statistical computing. $\mathrm{R}$ Foundation for Statistical Computing, Vienna, Austria. Tersedia pada https://www.R-project.org/.

Roca G, Alcoverro T, Krause-Jensen D, Balsby TJS, van Katwijk MM, Marbà N, Santos R, Arthur R, Mascaró O, Fernández-Torquemada Y, Pérez M, 
Duarte CM, Romero J. 2016. Response of seagrass indicators to shifts in environmental stressors: a global review and management synthesis. Ecological Indicator. 63: 310-323. https://doi.org/ 10.1016/j.ecolind.2015.12.007

Samper-Villarreal J. 2016. Seagrass morphometrics at species level in Moreton Bay, Australia from 2012 to 2013. Scientific Data. 4:170060. https://doi.org/ $10.1038 /$ sdata.2017.60

Setyawan E, Yusri S, Timotius S. 2011. Terumbu Karang Jakarta: Laporan Pengamatan Jangka Panjang Terumbu Karang Kepulauan Seribu (2005-2009). Yayasan Terumbu Karang Indonesia. $110 \mathrm{p}$.

Shipley B. 2009. Confirmatory path analysis in a generalized multilevel context. Ecology. 90: 363-368. https://doi.org/10.1890/08-1034.1
Van Tussenbroek BI, Vonk JA, Stapel J, Erftemijer PLA, Middelburg JJ, Zieman JC. 2006. The biology of Thalassia: Paradigms and recent advances in research. In: Larkum AWD, Orth RJ, Duarte CM. Eds. Seagrasses: Biology, Ecology and Conservation. Netherlands (NL): Springer. pp. 227254.

Vonk JA, Christianen MJA, Stapel J, O’Brien KR. 2015. What lies beneath: Why knowledge of belowground biomassadynamics is crucial to effective seagrass management. Ecological Indicators. 57: 259-267. https://doi.org/10.1016/j.ecolind.2015.05.008

Wahab I, Madduppa H, Kawaroe M. 2017. Seagrass species distribution, density and coverage at Panggang Island, Jakarta. IOP Conference Series: Earth and Environmental Science. 54012084. https://doi.org/10.1088/1755-1315/54/1/012084 